\title{
Response of Buttonwood (Conocarpus erectus) Trees to Drought Conditions
}

\author{
Ansary Edris Moftah* and Abdul-Rahman Ibrahim AL-Humaid
}

\author{
College of Agriculture and Veterinary Medicine \\ Qassim University, Saudi Arabia \\ P.O. Box, 1482 Burida, K.S.A.
}

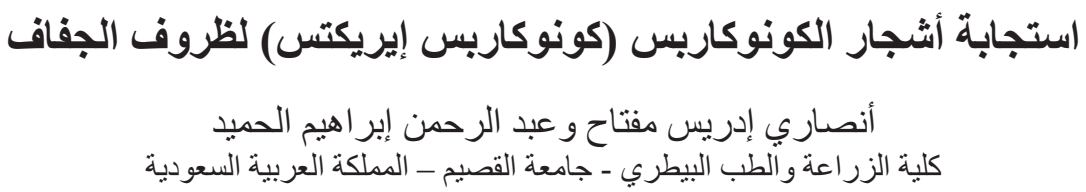

الخلاصة: تم تتمية بادرات أشجار الكونوكاربس البالغة من العمر ستة أشهر في تربة رملية تحت درجات مختلفة من الجهد المائي

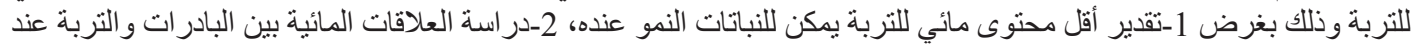

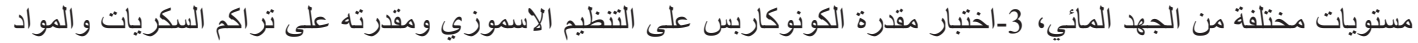
الصلبة حتى يتحمل جفاف التربة. وقد وجد أن نمو البادر ات لم يتأثر تأثثر ا معنويا عند تدني الجهد المائي للتربة حتى 10.1 ميجاباسكال (أي بين 40-30\% من السعة الحقلية)، و عندما نقص المحتوى الرطوبي للتربة عن ذلك فأن نمو البادرات، منمثلا في طول التئي النبات

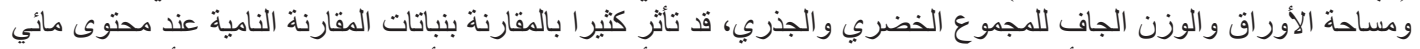

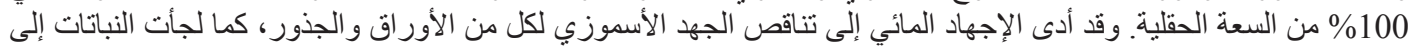

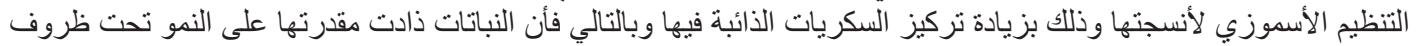

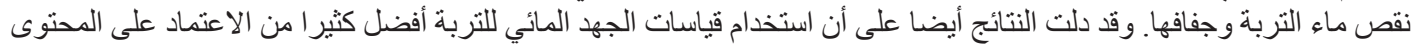

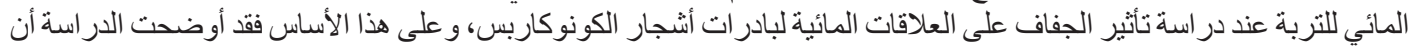

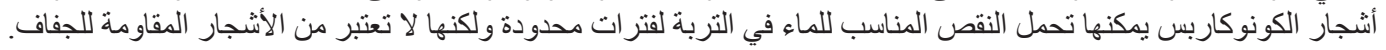

ABSTRACT: Six-month-old buttonwood (Conocarpus erectus L.) seedlings were grown in containers under different soil water potentials $\left(\Psi_{\text {soil }}\right)$. The objective of the work was: 1) to determine the minimum soil water potential at which Conocarpus trees can survive and grow fairly well, 2) to study the soil-plant water relationship at different irrigation regimes, and 3) to examine the capacity of Conocarpus seedlings for osmotic adjustment via solute accumulation. Seedling growth was not affected significantly at soil water potential above $-0.1 \mathrm{MPa}$ (between 40 and 30\% Field Capacity (FC). At lower $\Psi_{\text {soil }}$, plant height, leaf area and shoot and root dry weights became disrupted by water deficit. Water stress decreased the osmotic potential $\left(\Psi_{\pi}\right)$ of leaves and roots. Leaves tended to osmoregulate their cell sap through osmotic adjustment processes as their content of soluble sugars increased. The positive survival under low $\Psi_{\text {soil }}$ could be related to increased osmotic adjustment. $\Psi_{\text {soil }}$ values were found to be more useful than FC values to estimate water requirements and use over an extended period of time, for plants grown under different soil types and different environmental conditions. Conocarpus seedlings can withstand reasonable water stress and can survive at moderately low water potential but, in contrast to other studies, this can not be classified as a high drought tolerant or resistant species.

Keywords: Water stress, Conocarpus, growth, osmotic adjustment, osmotic potential.

\section{Introduction}

Buttonwood (Conocarpus erectus L.), an evergreen tree of the family Combretaceae, has been found to tolerate extreme desert heat where summer temperature may reach $47^{\circ} \mathrm{C}$ and to grow in soil of very low fertility (Branney, 1989). This tree deserves attention because it grows fairly rapidly and can endure the unrelenting fierce tropical sun and can survive high salinity levels if it is adequately supplied with water. It provides food and cover for wildlife, protects the soil during rainstorms and helps fix dunes against migration (Popp et al., 1989). It is widely 
planted as anornamental evergreen in yards, parking lots, streets, parks, and potted plants are used to form bonsai (Gliman and Watson, 1993). The wood is durable and is used to make railroad ties, posts, boats, fuel and charcoal. The bark and leaves have been used in tanneries and traditional medicine (Liogier, 1990).

Unfortunately, there is little information on the water use and requirements of buttonwood, as the case in other isolated landscape trees. Most of the information on $C$. erectus water use in Saudi Arabia, as in many other arid regions, is based on recommendations for low-water-use trees set by various organizations, such as the Environmental Protection Agency (Garbesi, 1992) and reported in the literature (Levitt et al., 1995, Nardini et al., 2000). Information on these species is usually based on experimental observations and the plant's native habitat, which are often not precise. Usually, minimum water requirements and drought survivability, rather than actual water use (Levitt et al., 1995) are studied. Correspondingly, buttonwood (Conocarpus sp.), for example, is reported to be highly drought tolerant (Gliman and Watson, 1993; Stevens et al., 2001), but its actual water use and requirement are not known.

Most methods of estimating water use of isolated trees consist of direct gravimetric measurements, such as measuring water consumption or transpiration. Soil moisture readings and potential are useful tools to determine how much water is available for the crop, when to start irrigating, and how much water to apply. The objective of this study was: 1) to determine the minimum soil water potential at which $C$. erectus can survive and grow fairly well, 2) to find the relationship between soil water potential and plant water potential at different irrigation regimes, and 3) to compare the variations in plant osmotic potentials and osmotic adjustment of $C$. erectus seedlings in response to water stress.

\section{Materials and Methods}

Field experiments were conducted at the Research Station of the College of Agriculture and Veterinary Medicine in Al-Qassim, Saudi Arabia, between May 2 and September 15, 2003. The weather during the experiment was characterized by sunny, hot, dry days and warm nights. The average daily maximum temperature was $37.6{ }^{\circ} \mathrm{C}$ with little variation. The daily minimum temperature during the experiment ranged from 15.6 to $28.5^{\circ} \mathrm{C}$. No rain fell during the experimental period.

Six-month old buttonwood (Conocarpus erectus L.) seedlings were transferred from nursery soil in the greenhouse to $30-\mathrm{L}$ plastic containers filled with $40 \mathrm{~kg}$ sandy soil each. The seedlings, averaging $75 \pm 4.5 \mathrm{~cm}$ tall with a caliper of $2.5 \pm 0.3 \mathrm{~cm}$ at the soil line, were grown outdoors under natural conditions in a shadefree location. Containers were sunk in the ground such that the surface of the potted soil was at approximately the level of the surrounding ground surface. Empty containers were used as sleeves to line the holes so that the plant-holding containers could be removed and replaced easily. The tops of the containers were covered with white polyethylene film to minimize evaporation.

A completely randomized design with 10 replicates for each treatment was used in this experiment. Seedlings of uniform height (one seedling per pot) were located in lines with a spacing of $2 \mathrm{~m}$ between lines and $1 \mathrm{~m}$ between pots to avoid mutual shading. The ground surface between and surrounding the trees consisted of bare soil. At the time of transplanting, all trees were fertilized with the complete water-soluble fertilizer "Sangral" compound fertilizer (20N-20P$20 \mathrm{~K}$, plus micronutrients) at the rate of $600 \mathrm{~kg} \mathrm{ha}^{-1}$. Each tree received a total of $10 \mathrm{~g}$ fertilizer.

For the first 4 weeks, all seedlings were watered to field capacity (FC), supplying an amount of water equal to transpiration losses: pots were weighed every other day, to ensure the establishment of seedlings and to allow adaptation to field conditions before water stress was imposed. By the end of this period, pots had received an amount of water equal to $100,80,60,40$, 20 , or $10 \%$ of FC and were then allowed to grow for 4 more weeks. FC was determined gravimetrically and found to be $12 \%$. Each water treatment consisted of 10 seedlings. At the time of transplanting, five seedlings identical to those used in the experiment were separated to roots, stems, and leaves, then oven-dried at $70^{\circ} \mathrm{C}$ until constant weight, and weighed separately.

\section{Measurements}

Soil measurements. At each water regime treatment, soil water potential was measured using tensiometers, and soil water content was measured gravimetrically using an electronic balance (Mittler EB60, Hightstown, NJ) as described by Ranney et al. (1991). 
The relation between amount of soil moisture as $\%$ of FC and soil water potential was established by the pressure plate apparatus, described by Shock et al. (2002) in which, saturated soil samples were set on a plate composed of a porous membrane. The membrane was placed in a pressure cooker type chamber and sealed. The soil was then subjected to a selected series of pressures. The pressure in the chamber forced the water out of the soil through the membrane. After equilibrium was established at each pressure step, a soil sample was taken from the chamber and the amount of water in the soil determined gravimetrically.

\section{Plant measurements}

Plant water relations: Predawn $\left(\psi_{\mathrm{pd}}\right)$ and midday $\left(\psi_{\mathrm{md}}\right)$ leaf water potential was determined in eight randomly chosen leaves from each irrigation regime, using a pressure chamber (PMS Instrument Co., Corvallis, OR, USA) as described by Scholander et al. (1965). The sampled leaves were enclosed in a polyethylene bag just before detaching them from the plant and conserved in a thermal isolated box. The measurements were made as soon as possible using a pressure increment of $0.1 \mathrm{MPa}$ per 2 or 3 seconds.

Osmotic pressure was determined as described by Ranney et al. (1991). Terminal-fully-expanded and middle leaf and root samples were collected before dawn to minimize variation in solute accumulation during the light period. Roots were excised at a point where the root diameter was $5 \mathrm{~mm}$ and included the portion of the root system distal to the excision. Excised tissue was hydrated by recutting under water and holding for 2 hours, covered with plastic, in the dark, with the cut end submerged. This method was sufficient to fully rehydrate tissues, i.e., result in a water potential of $0 \mathrm{MPa}$. Osmotic potential $\left(\Psi_{\pi}\right)$ was determined on expressed sap from fully hydrated tissue after freezing and thawing. Osmolality of expressed sap was determined using a vapor pressure osmometer (Wescor model 5100C, Logan, Utah). $\Psi_{\pi}$ potential of the expressed sap was then calculated for $20^{\circ} \mathrm{C}$, based on the van't Hoff relation as given by Nobel (1999):

$$
\begin{gathered}
\Psi_{\pi}(\mathrm{MPa})=0.002437\left(\mathrm{~m} 3 \cdot \mathrm{MPa} \cdot \mathrm{mol}^{-1}\right) \times \\
\text { osmolality }\left(\mathrm{mol} \cdot \mathrm{m}^{-3}\right)
\end{gathered}
$$

Turgor potential $\left(\Psi_{\mathrm{p}}\right)$ was calculated by subtracting $\Psi_{\pi}$ from $\Psi_{\mathrm{w}}$ and osmotic adjustment was calculated as the difference in osmotic potential at full turgor between control (100\% FC) and stressed plants (Blum, 1989).

Soluble sugar analysis: Total soluble sugars were analyzed in terminal leaves, mature leaves and roots after 30 days of the onset of the irrigation treatments. Soluble sugars were determined using the phenolsulfuric acid method described by Dubois et al. (1956) and developed by Buysse and Merckx (1993). Briefly, $50 \mathrm{mg}$ of dry leaf powder was extracted with $80 \%$ $(\mathrm{v} / \mathrm{v})$ ethanol three times $(20 \mathrm{~mL})$. The total volume of the combined and filtered extracts was adjusted to $100 \mathrm{~mL}$ using deionized water. One milliliter of samples was transferred into a glass tube, and $1 \mathrm{~mL} 18$ $\%(\mathrm{w} / \mathrm{v})$ phenol solution was then added. Immediately afterwards, $5 \mathrm{~mL}$ of concentrated sulphuric acid were added, the solution in the tube was mixed using a vortex mixer. The tubes were allowed to stand for $20 \mathrm{~min}$, and cooled to room temperature before absorbance was measured with a spectrophotometer at $490 \mathrm{~nm}$ (Genesys, Spectronic Instruments, Inc., Rochester, NY, USA). The contribution of soluble sugars to the osmotic potential of the expressed sap was calculated based on the relative dry weight (RDW) at saturation [dry weight/ (saturated weight - dry weight)], the solute concentration, and the van't Hoff relation.

Transpiration: Cumulative transpiration was measured gravimetrically and water use efficiency (WUE) was determined by dividing total dry matter production by the cumulative amount of water used throughout the growth period.

Growth analysis: Shoot length, leaf area per plant (measured with a leaf area meter LI-COR Model 3100, Lincoln, NE), and dry weight of plants were recorded at harvest. The decision to harvest any particular treatment was based on the need to do so at the beginning of death symptoms and before deaths began to occur. Dry weights were determined after drying at $70{ }^{\circ} \mathrm{C}$ till constant weights. Leaves dropped during water-stress treatment were included.

Relative growth rate (RGR) was measured according to the equation:

$$
\mathrm{RGR}=\left(\ln \mathrm{W}_{2}-\ln \mathrm{W}_{1}\right) /\left(\mathrm{t}_{2}-\mathrm{t}_{1}\right)
$$

where $\ln$ is the natural logarithm and $\mathrm{W}_{1}$ and $\mathrm{W}_{2}$ are total dry weight (wt) at times (t) 1 and 2, respectively. The experiment was arranged in a completely randomized design and was analyzed by analysis 


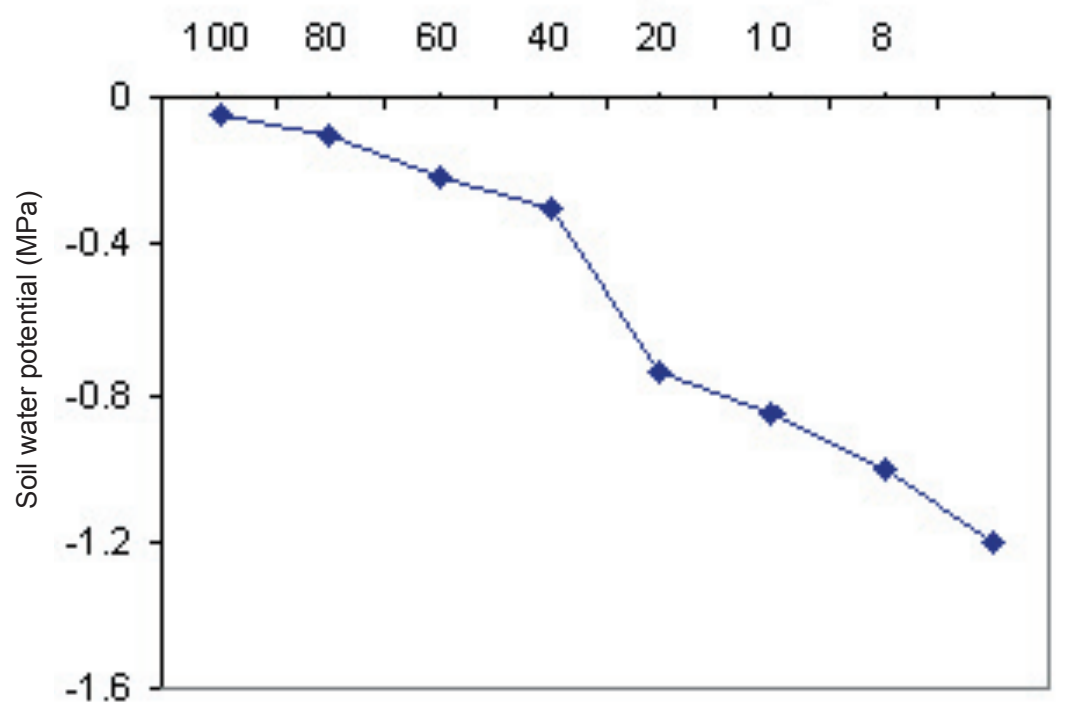

Figure 1. Relationship between soil water content and soil water potential (MPA).

of variance. All data were statistically analyzed by ANOVA according to Snedecor and Cochran (1980) with the aid of COSTAT computer program for statistics. Differences among treatments were tested with LSD at $5 \%$ level of significance.

\section{Results and Discussion}

Expression of soil moisture status in terms of soil water potential reveals much more than just the amount of moisture. Soil water at FC is readily available to plants and sufficient air is present for root and microbial respiration. The optimum water content for plant growth and soil microbial respiration is considered to be close to FC. Thus, high growth rate is expected to occur at or near FC. Data in Figure 1 show that at FC, sandy soil used in this experiment was found to be holding water at a tension of about $-0.015 \mathrm{MPa}$.

Permanent wilting and symptoms of death did not appear until soil water potential reached about $-1.5 \mathrm{MPa}$, below which, plants were not able to tolerate severe drought or revive after rewatering. In contrast to Gliman and Watson (1993), who reported that $C$. erectus is a highly drought tolerant tree, the present results indicate that $C$. erectus seedlings can withstand reasonable soil water stress (less than -1.5
$\mathrm{MPa}$ ) and can survive at moderately low $\Psi_{\text {soil }}$, but can not be classified as a highly drought tolerant or drought resistant species which can survive at a lower $\Psi_{\text {soil }}$, as described by Kramer and Boyer (1995). The differences between the early and the present studies may be attributed to the differences between environmental conditions. Vapor pressure deficit (VPD) between leaves and air is highly dependent on environmental parameters that might be differing in both studies.

Seedling growth was not affected significantly until soil water potential was lower than $-0.1 \mathrm{MPa}$ (between 40 and $30 \%$ FC), after which plant height, leaf area and shoot and root dry weights became disrupted by the interruption in water status as they were severely reduced by soil water deficit (Figures 2 and 3). Leaf area per plant was the growth parameter most affected by low soil-water potential, causing a considerable reduction in the rate of leaf production, which, in part, accounted for the effect of drought on leaf biomass production. The reduction in leaf area per plant was about $70 \%$ at soil water potential of $-0.3 \mathrm{MPa}(20 \% \mathrm{FC})$ compared to that at $100 \% \mathrm{FC}$ $(-0.015 \mathrm{MPa})$. The corresponding reduction in shoot dry weight was about $40 \%$ at the same soil water potential. 

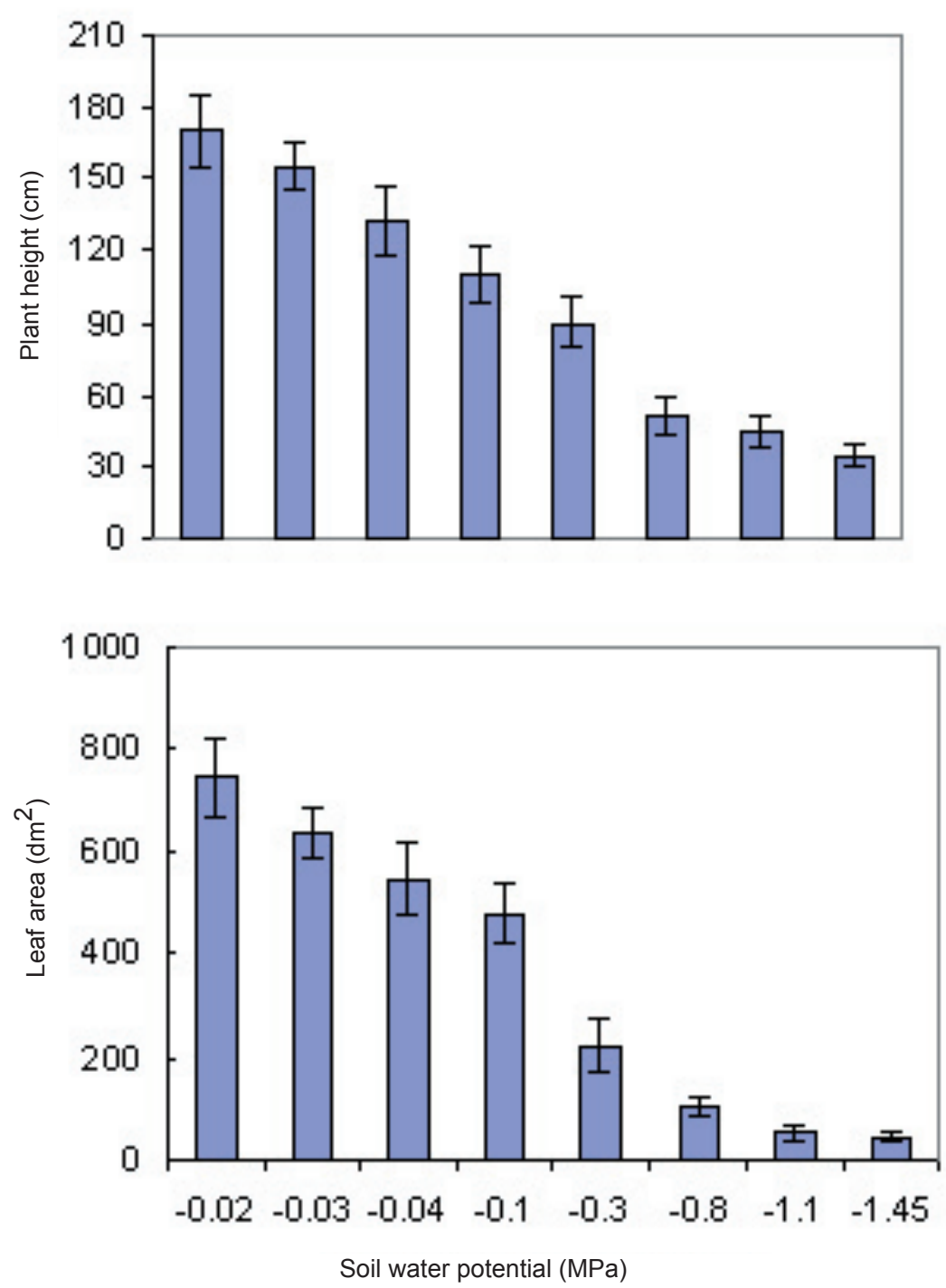

Figure 2. Effect of soil water potential on plant height and leaf area per plant $(n=6)$. Vertical bars indicate standard error of the mean.

Reduction in plant growth is one of the most conspicuous effects of water deficit on the plant and is mainly caused by inhibition of leaf expansion and stem and root elongations when water potential decreases below a threshold which differs among species (Kramer and Boyer, 1995). Because turgor reduction is the earliest significant biophysical effect of water stress, turgor-dependent activities, such as leaf expansion and cell elongation, are the most sensitive to water deficit. This reality is based on the fact that cell expansion is a turgor-driven process and is extremely sensitive to water deficit according to the equation

$$
\mathrm{GR}=m\left(\Psi_{\mathrm{p}}-\gamma\right)
$$

where GR is the growth rate, $\Psi_{\mathrm{p}}$ is the turgor, $\gamma$ is the pressure below which the cell wall resists deformation, and $m$ is the wall extensibility. Therefore, a small decrease in plant water content and turgor can substantially decrease the relative growth rate (Figure 

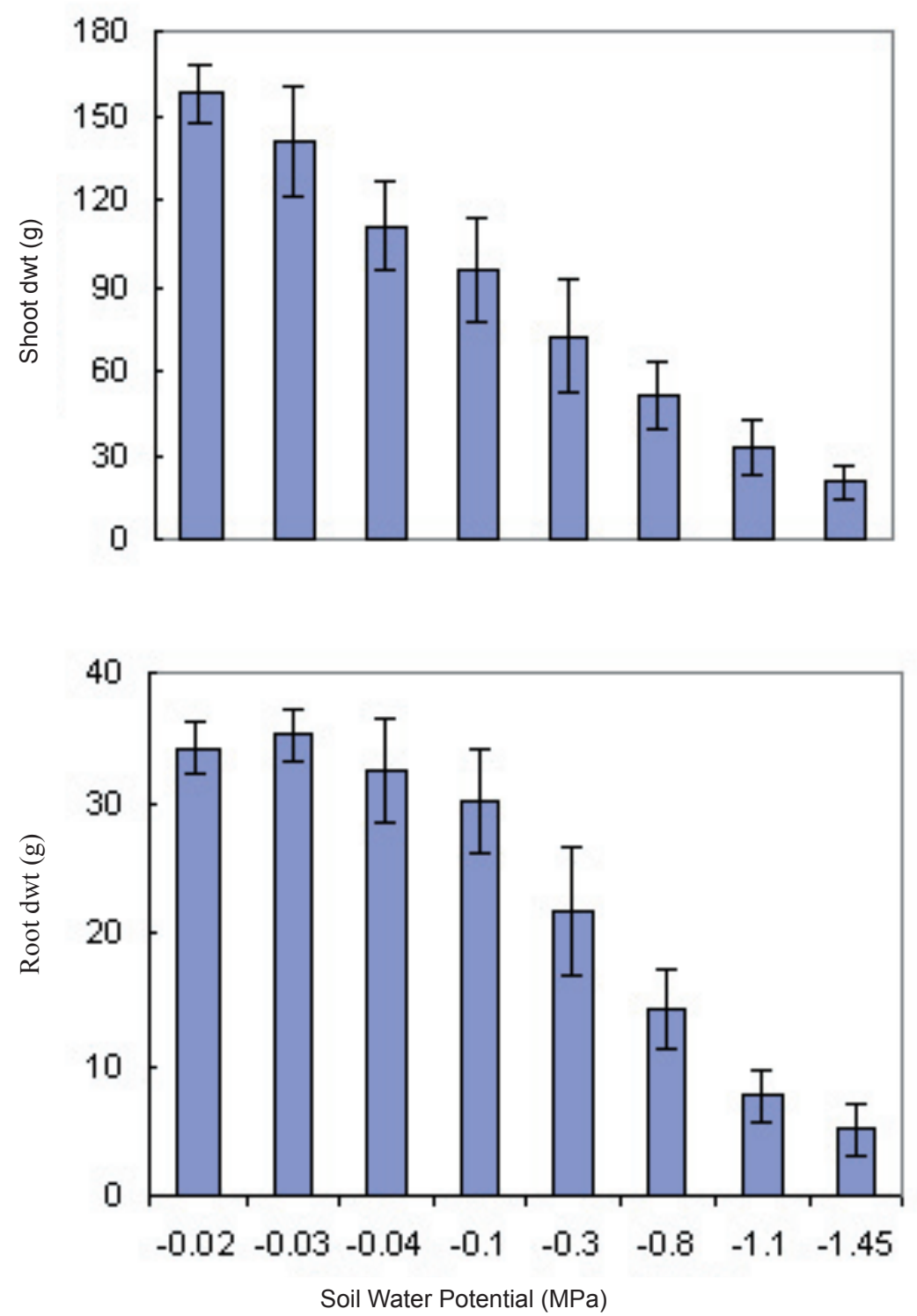

Figure 3. Effect of soil water potential on shoot and root dry weights $(n=6)$. Vertical bars indicate standard error of the mean.

4) and slow down or fully stop growth (Taiz and Zeiger, 2002).

Moreover, water deficit episodes in field conditions are frequently associated with high radiation, thus water deficit is an important limitation factor to plant growth and production in arid and semi-arid regions (Delperee et al., 2003). Typically, as the water content of the plant decreases by water deficit, its cells shrink. This decrease in cell volume results in lower turgor pressure and the subsequent concentration of solutes in the cell. Because growth is dependent mainly on cell turgor (Leuschner et al., 2001) and turgor pressure is very sensitive to water deficit, it decreases sharply with little change in plant water content. In an early study, Nilsen and Orcutt (1996) pointed out that the quantity and quality of 
plant growth depend on cell division, enlargement, and differentiation, and all these parameters are affected by water deficit because all of them are dependent on turgor pressure. Lowering turgor potential and consequent inhibition of cell expansion as a result of water deficit conditions was reported to slow plant growth and to reduce the number of leaves as plants became shorter (Taiz and Zeiger, 2002).

Also, root mass production decreases progressively with decreasing soil water potential (Figure 3). This decrease in root growth was associated with decreased root osmotic potential and, consequently, decreases turgor pressure (Figure 5). It appears that osmotic adjustment in roots occurred at soil water potential lower than $-0.40 \mathrm{MPa}$ (Figure 5). Over a range in soil water potential of -0.015 (FC) to nearly $-1.0 \mathrm{MPa}$, root osmotic potential fell about $0.37 \mathrm{MPa}(35 \%)$ whereas P fell about $0.75 \mathrm{MPa}(60 \%)$.

The increase in root/shoot ratio with decreasing water potential indicates the more severe reduction
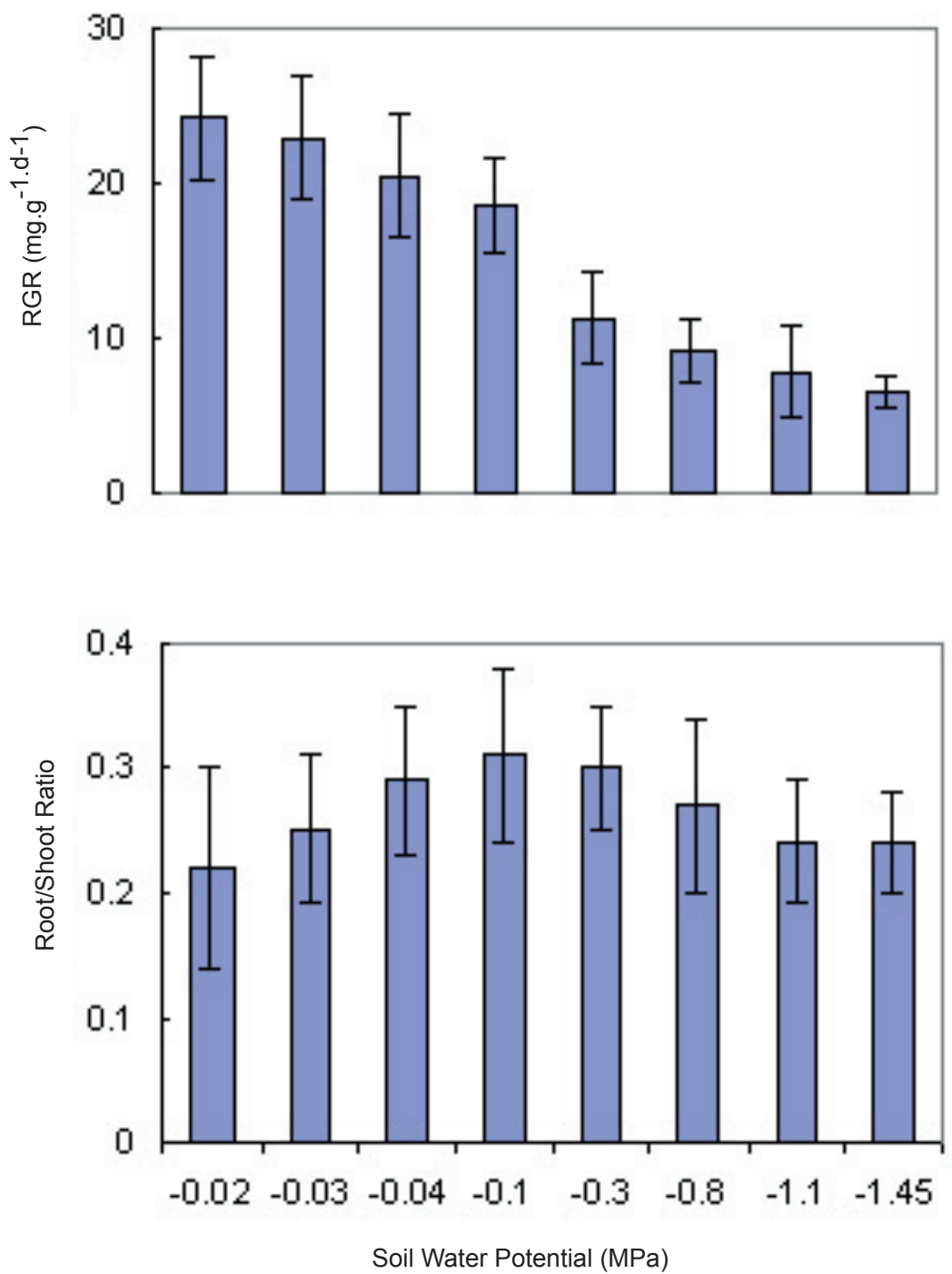

Figure 4. Effect of soil water potential on relative growth rate (RGR) and root/shoot ratio $(n=6)$. Vertical bars indicate standard error of the mean. 
Soil water potential $(\mathrm{MPa})$
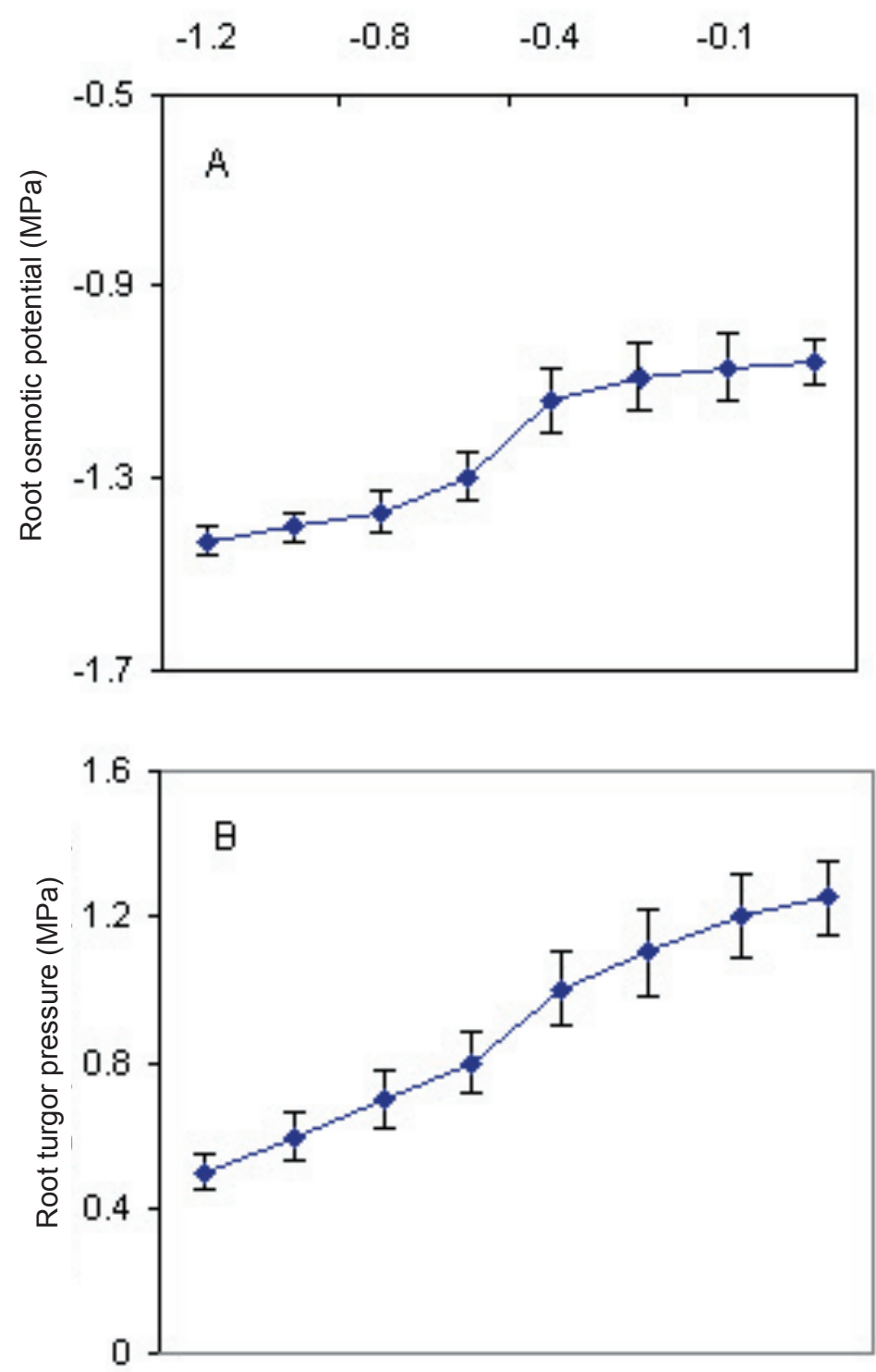

Figure 5. Effect of soil water potential on root turgor potential and root osmotic potential (MPa). Vertical bars indicate estandard error of the mean ( $\mathrm{n}=6$ roots).

in shoot than root growth with decreasing soil water potential (Figure 4). It is frequently observed that drought increases allocation to roots (Kramer and Boyer, 1995). It may be that ABA plays a role in inhibiting shoot growth, since it has a negative effect on photosynthesis through its effects on stomatal opening, gas exchange, and pigment formation, more than its effect on root growth (Hsiao and $\mathrm{Xu}$, 2000). Finally, the reduction in leaf growth leaves more assimilates free to go to roots (Leuschner et al., 2001).

Water stress decreased $\Psi_{\pi}$ of $C$. erectus leaves and roots (Table 1). It is clear that fully expanded upper leaves have higher $\Psi_{\pi}$ than lower (older) 
Table 1. Effect of water regime on total soluble sugar concentration ( $\left.\mathrm{mmol} \cdot \mathrm{kg}^{-1} \mathrm{dry} \mathrm{wt}\right)$, and calculated osmotic potential $\left(\Psi_{\pi}\right)$ for fully expanding upper and lower leaves and roots of Conocarpus seedlings. FC = Field capacity; values represent means of 3 measurements. Means followed by the same letter(s) within a column are not significantly different using $\operatorname{LSD}_{(0.05)}$ compraisons.

\begin{tabular}{ccccccccc}
\hline \multirow{2}{*}{$\begin{array}{c}\text { Water regime } \\
(\% \mathrm{FC})^{1}\end{array}$} & \multicolumn{2}{c}{ Upper leaves } & & \multicolumn{2}{c}{ Lower leaves } & & \multicolumn{2}{c}{ Roots } \\
\cline { 2 - 3 } \cline { 7 - 8 } \cline { 7 - 8 } \cline { 8 - 9 } & mmol sugar & $\Psi_{\pi}(\mathrm{MPa})$ & & mmol sugar & $\Psi_{\pi}(\mathrm{MPa})$ & & mmol sugar & $\Psi_{\pi}(\mathrm{MPa})$ \\
\hline 100 & $365.3 \mathrm{c}$ & $-0.26 \mathrm{c}$ & & $415.2 \mathrm{~d}$ & $-0.41 \mathrm{~d}$ & & $114.5 \mathrm{c}$ & $-0.12 \mathrm{~d}$ \\
80 & $410.7 \mathrm{~b}$ & $-0.53 \mathrm{~b}$ & & $488.3 \mathrm{c}$ & $-0.75 \mathrm{c}$ & & $165.5 \mathrm{~b}$ & $-0.14 \mathrm{c}$ \\
60 & $482.7 \mathrm{a}$ & $-0.88 \mathrm{a}$ & & $531.5 \mathrm{~b}$ & $-0.94 \mathrm{~b}$ & & $196.2 \mathrm{~b}$ & $-0.18 \mathrm{~b}$ \\
40 & $513.4 \mathrm{a}$ & $-0.92 \mathrm{a}$ & & $622.3 \mathrm{a}$ & $-1.22 \mathrm{a}$ & & $250.1 \mathrm{a}$ & $-0.21 \mathrm{a}$ \\
\hline
\end{tabular}

leaves. Interestingly, when stressed, all leaves tended to osmoregulate their cell sap as leaves adjusted osmotically. As soil water potential fell from -0.015 $\mathrm{MPa}(100 \% \mathrm{FC})$ to $-1.0 \mathrm{MPa}(40 \% \mathrm{FC})$ the upper leaves showed the greatest decrease in osmotic potential $(0.60 \mathrm{MPa})$, while lower leaves typically decreased by $0.47 \mathrm{MPa}$ (Table 2). The roots had substantially higher $\Psi_{\pi}$ than leaves, with an osmotic potential of -0.44 and $-0.80 \mathrm{MPa}$ at 100 and $40 \%$ FC treated plants, respectively. The higher osmotic potential of roots than of leaves is consistent with work done on other woody species, including Juglans nigra and Quercus spp. (Parker and Pallardy, 1988), and Prunus avium (Ranney et al., 1991). But it should be noted that, although $\Psi_{\pi}$ is typically higher in roots than leaves, the greater elasticity of root tissue can contribute to decreased water content and increased solute concentration as tissue water potential declines, resulting in similar water potential at the turgor loss point for both leaves and roots (Ranney et al., 1991).
Total soluble sugars increased in response to water stress in leaves and roots. Estimates of the contribution of total soluble sugars to the $\Psi_{\pi}$ of the expressed sap of leaves and roots showed that sugars accounted for a large percentage when plants were exposed to severe drought conditions. The contribution reached about $50-60 \%$ in leaves and about $25 \%$ in roots (Table 2). Generally, the stress-induced reduction in $\Psi_{\pi}$ could be accounted for by increasing levels of soluble sugars. The capacity for osmotic adjustment via solute accumulation (including soluble sugars) has been reported for many woody plants (Paker and Pallardy, 1988; Ranney et al., 1991). Higher sugars and other solute concentrations contribute to lower tissue osmotic potential, maintenance of turgor potential, and improved tolerance of low tissue water potentials (Tyree et al., 2001).

In early studies, Ranney et al. (1991) found that osmotic potentials of expanding terminal leaves of water-stressed apple and cherry trees, respectively,

Table 2. Effect of water regime on the contribution of soluble sugars to the measured osmotic potential $\left(\Psi_{\pi}\right)$ of Conocarpus leaves and roots. $\mathrm{FC}=$ Field capacity; Calc. $=$ calculated, Measu. $=$ measured; values represent means of 3 measurements. Means followed by the same letter(s) within a column are not significantly different using $\operatorname{LSD}_{(0.05)}$ comprarisons.

\begin{tabular}{|c|c|c|c|c|c|c|}
\hline \multirow{2}{*}{$\begin{array}{l}\text { Water regime } \\
\qquad(\% \mathrm{FC})^{1}\end{array}$} & \multicolumn{2}{|c|}{ Upper leaves } & \multicolumn{2}{|c|}{ Lower leaves } & \multicolumn{2}{|c|}{ Roots } \\
\hline & $\begin{array}{c}\text { Measu. } \Psi_{\pi} \\
(\mathrm{MPa})^{2}\end{array}$ & $\begin{array}{c}\text { \% Calc./ } \\
\text { Measu. }\end{array}$ & $\begin{array}{c}\text { Measu. } \Psi_{\pi} \\
(\mathrm{MPa})\end{array}$ & $\begin{array}{l}\% \text { Calc./ } \\
\text { Measu. }\end{array}$ & $\begin{array}{c}\text { Measu. } \Psi_{\pi} \\
(\mathrm{MPa})\end{array}$ & $\begin{array}{l}\text { \% Calc./ } \\
\text { Measu. }\end{array}$ \\
\hline 100 & $-1.24 \mathrm{c}$ & $21 \mathrm{c}$ & $-1.45 \mathrm{c}$ & $28 \mathrm{c}$ & $-0.44 \mathrm{~d}$ & $27 \mathrm{a}$ \\
\hline 80 & $-1.46 \mathrm{~b}$ & $36 \mathrm{~b}$ & $-1.77 \mathrm{~b}$ & $42 \mathrm{~b}$ & $-0.55 \mathrm{c}$ & $25 \mathrm{~b}$ \\
\hline 60 & $-1.76 \mathrm{a}$ & $50 \mathrm{a}$ & $-1.94 \mathrm{a}$ & $48 \mathrm{~b}$ & $-0.64 b$ & $28 \mathrm{a}$ \\
\hline 40 & $-1.84 \mathrm{a}$ & $50 \mathrm{a}$ & $-1.92 \mathrm{a}$ & $64 \mathrm{a}$ & $-0.83 a$ & $25 \mathrm{~b}$ \\
\hline
\end{tabular}


were higher than those of older leaves. Other studies have found that soluble sugars and sorbitol (a sugar alcohol) are synthesized primarily in older leaves, suggesting that osmotic adjustment in expanding leaves resulted either from increased translocation of soluble sugars and sorbitol to young leaves or from a decreased rate of the metabolism of both compounds, resulting in their accumulation in young leaves under water stress conditions without being disruptive to cell organelles, enzymes, and membrane-bound processes (Taiz and Zeiger, 2002; Wang et al., 2003). Water soluble sugars have been found to be associated with osmotic adjustment in response to water stress in some plant species (Wang et al., 2003). In the present study, soluble sugar content was higher under prolonged and severe drought stress conditions than under wet conditions. Barathi et al. (2001) found that increases in soluble sugar content during prolonged drought stress were accompanied by decreases in starch, protein, and nucleic acids, which indicates drought injury.

Data in Figure 6 shows that when the soil was held close to FC $(-0.015 \mathrm{MPa})$ leaf water potential $\left(\Psi_{\text {leaf }}\right)$ fell from $-0.05 \mathrm{MPa}$ in the morning to $-0.8 \mathrm{MPa}$ in the middle of the day. During drying, $\Psi_{\text {leaf }}$ progressively decreased with decreasing $\Psi_{\text {soil }}$ to reach its minimum $(-0.75 \mathrm{MPa})$ as soil became severely dry $\left(\Psi_{\text {soil }}=-1.45\right.$ $\mathrm{MPa})$. The corresponding value of midday $\Psi_{\text {leaf }}$ was $-2.8 \mathrm{MPa}$. Menzel et al. (1986) reported that $85 \%$ of the variation in $\Psi_{\text {leaf }}$ could be attributed to the negative response to leaf-air vapor pressure deficit (VPD). There is not likely to be much response to soil water potential or irrigation when the air is dry. Wet soil alone did not prevent development of low leaf water potential of lychee trees when the air was dry (Menzel et al. (1986).

In this respect, Scholander et al. (1965) gave a good survey of the water potential ranges of species from different habitats. They found no values below $-2.5 \mathrm{MPa}$ for forest trees. Richter (1997) also listed the minimal water potentials from contrasting environments for woody species from temperate regions and gave a range between -1.5 and -2.5 MPa. C. erectus showed fairly low $\Psi_{\text {leaf }}$ that reached about $-2.8 \mathrm{MPa}$ at midday and survived at rewatering. This low $\Psi_{\text {leaf }}$ is comparable with the minima found on Chaparral shrubs (-3 to $-4 \mathrm{MPa})$

Soil water potential (MPa)

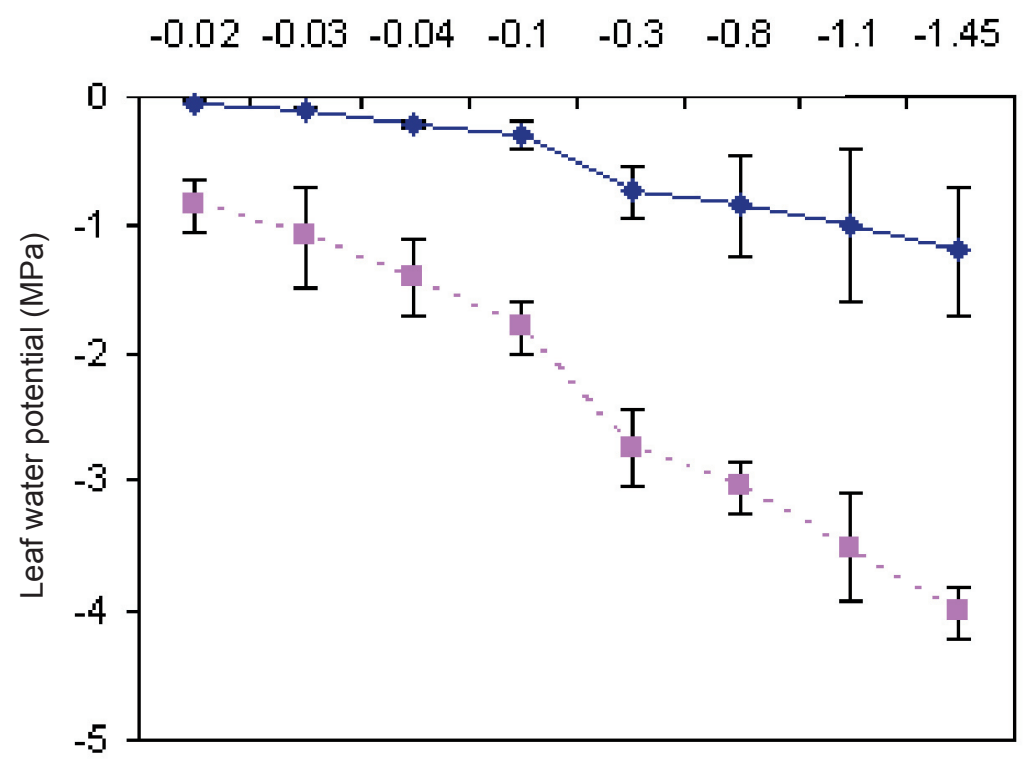

Figure 6. Effect of soil water potential on predawn (solid line) and midday (dashes line) water potential (MPa) of Conocarous plants. Vertical bars indicate standard error of the mean ( $\mathrm{n}=6$ leaves). 
as reported by Bowman and Roberts (1985). This means that the hydraulic conductivity of the roots can be maintained even as the soil water potential fell below -1.4 MPa during drought periods. For water stress sensitive species, total blockage of sap flow might occur at potential of $-1.2 \mathrm{MPa}$ (Kramer and Boyer, 1995). Therefore, only small fluctuations of field water potential are tolerable for these species to maintain vitality. So, $C$. erectus may be considered as a moderately drought-tolerant species.

Data in Figure 7 show that cumulative transpiration was reduced with decreasing $\Psi_{\text {soil, }}$ particularly under severe drought conditions. The decrease in cumulative water loss may be attributed to the decrease in transpiration rate under water deficit (Kramer and Boyer, 1995). It should be understood that the water potential of the trees was kept relatively high by quite sensitive stomatal control of transpiration (Vogt and Losch, 1999), and this may contribute to drought survival. The suppression of transpiration at severely low $\Psi_{\text {soil }}$ may be a reason for the diminishing differences between $\Psi_{\text {soil }}$ and the morning $\Psi_{\text {leaf }}(\mathrm{Ni}$ and Pallardy, 1991).

There was a tendency for increasing values of water use efficiency (WUE) with a decrease in the soil water content (Figure 7). It is clear that WUE increased as $\Psi_{\text {soil }}$ decreased to $-0.8 \mathrm{MPa}$ followed by a decline at lower water potential. These results agree well with those reported by Mielke et al. (2000) on Eucalyptus grandis. Under moderately drought condition it seems that $\mathrm{C}$. erectus can regulate stomata without prejudicing the amount of water ultimately transpired.
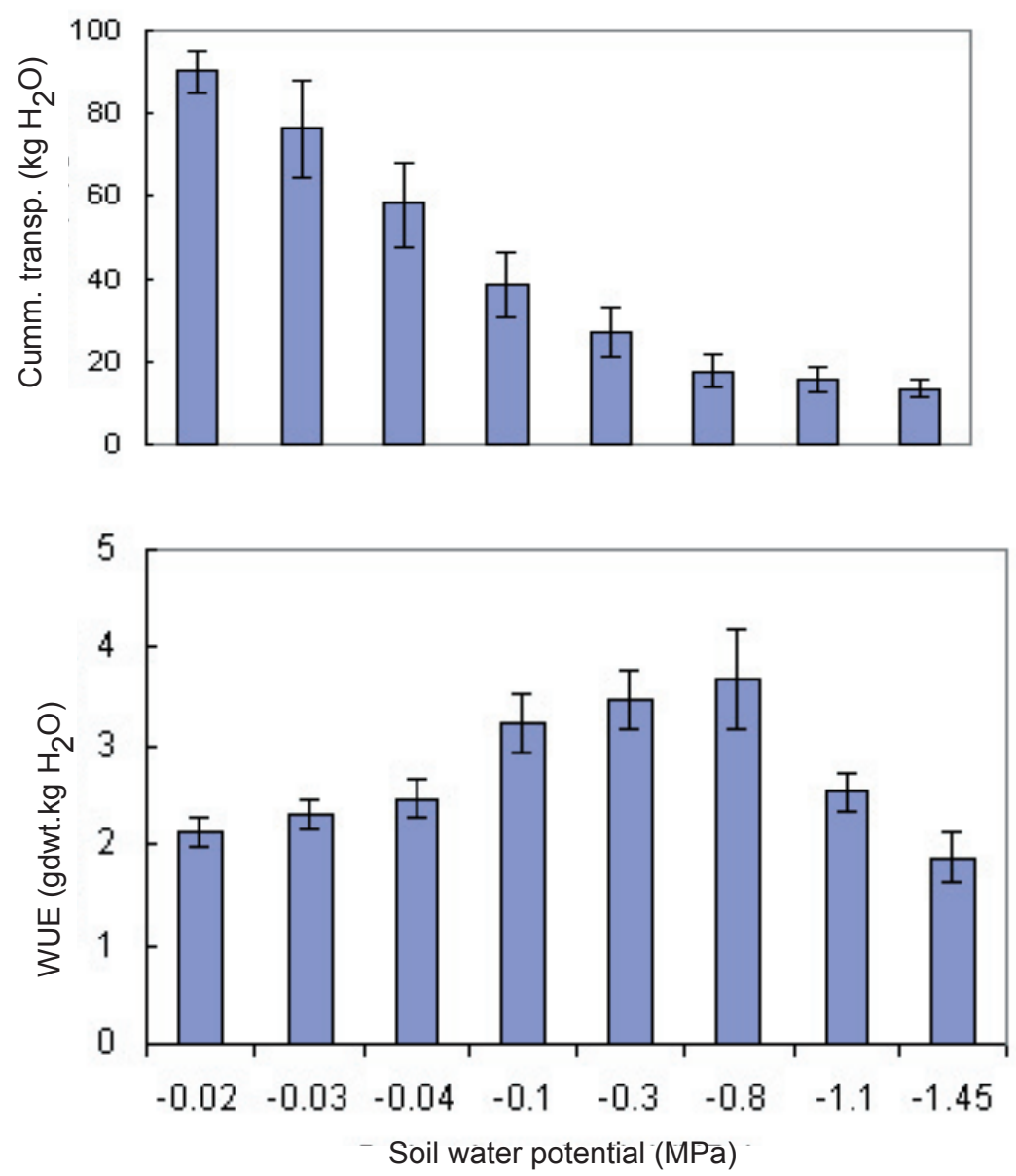

Figure 7. Effect of soil water potential on cumulative transpiration and water use efficiency of Conocarpus (n=6). Vertical bars indicate standard error of the mean. 
It may maintain higher stomatal conductance and this probably enables high dry matter accumulation. As the soil was allowed to dry behind a critical value, both photosynthesis and conductance decreased causing a marked decrease in WUE. Similar relationships were also found on Quercus alba (Ni and Pallardy, 1991) and Eucalyptus trees (Li, 2000). Morvant et al. (1998) found that Poinsetta plants acclimated to the water limitation by increasing their photosynthetic WUE. They reported that with an increase in WUE, the drought-treated plants were better able to utilize internal $\mathrm{CO}_{2}$ for photosynthesis.

$\mathrm{Li}$ (2000) explained the influence of WUE on plant growth and stated that increasing WUE could theoretically either increase or decrease biomass productivity. When water is limited, plants that use a finite water supply more efficiently would grow more rapidly. In this situation, high WUE would positively affect plant growth. Moreover, the partial closure of stomata increases WUE and restricts photosynthesis relative to plants with fully opened stomata. This strategy would result in a negative correlation between WUE and plant biomass productivity (Makela et al., 1996). In the present study $C$. erectus followed the latter strategy, as did those in a study by Tuomela (1997) and Li (2000), who also found that increasing WUE could decrease plant dry matter production.

\section{Conclusions}

Based on the results of this experiment, the use of soil water potential values seems to be a more useful tool than $\mathrm{FC}$ values for estimating water requirements and use in $C$. erectus seedlings over an extended period of time.

C. erectus was found to tolerate a moderate soil water stress over a long period of time rather than a severe stress for a short time. Growing plants at $\Psi_{\text {soil }}$ of -0.1 to $-0.2 \mathrm{MPa}$ had only a slight effect on the height, the leaf area, and the dry weight of $C$. erectus seedlings, and the effect was quickly reversed on rewatering. Severe drought caused a substantial reduction in the leaf production, which in part accounts for the effect of drought on plant biomass production. Root elongation decreased progressively with decreasing $\Psi_{\text {soil }}$ and was associated with decreased $\Psi_{\pi}$ and decreased turgor pressure. Osmotic adjustment occurred at $\Psi_{\text {soil }}$ of less than $-0.4 \mathrm{MPa}$. Decreased $\Psi_{\pi}$ in roots was caused by accumulation of osmotica, particularly soluble sugars, in the root cells. The relationship between plant growth and WUE may provide a basis for selecting genotypes with improved drought adaptation and biomass productivity. Midday plant water potential measurements may be a relevant and applicable indicator for irrigation scheduling in $C$. erectus trees.

\section{References}

Barathi, P., D. Sunder and A.R. Reddy. 2001. Changes in mulberry leaf metabolism in response to water stress. Biologia Plantarum 44:83-87.

Blum, A. 1989. Osmotic adjustment and growth of barley genotypes under drought stress. Crop Science 29:230-233.

Bowman, W.D. and S.W. Roberts. 1985. Seasonal and diurnal water relations adjustments in three evergreen chaparral shrubs. Ecology 66:738-742.

Branney, P. 1989. Propagation of tree species for afforestation in northern Sudan. Northern Region Irrigation Project (NRIRP), Forestry Development Component. Overseas Development Administration, London, UK, 42pp.

Buysse, J. and R. Merckx. 1993. An improved colorimetric method to quantify sugar content of plant tissue. Journal of Experimental Botany 44: 1627-1629.

Delperee, C., J.M. Kinet and S. Lutts. 2003. Low irradiance modifies the effect of water stress on survival and growth-related parameters during the early developmental stages of buckwheat (Fagopyrum esculentum). Physiologia Plantarum 119:211-220.

Dubois, M.K., J. Gille and F. Smith. 1956. Colorimetric method for determination sugar and related substances. Annals of Chemistry 28:350.

Garbesi, K. 1992. Estimating Water Use by Various Landscape Scenarios. Cooling our Communities - A Guidebook on Tree Planting and Light-colored Surfacing. Lawrence Berkeley Laboratory and U.S. Environmental Protection Agency. p. 157172 .

Gliman, E.F and D.G. Watson. 1993. Conocarpus erectus: Buttonwood. Fact sheet ST-179. U.S. Forest Service and Southern Group of State Foresters, Gainseville, FL. 3pp.

Hsiao, T.C and L.K. Xu. 2000. Sensitivity of growth of roots versus leaves to water stress: biophysical 
analysis and relation to water transport. Journal of Experimental Botany 51:1595-1616.

Kramer, P.J. and J.S. Boyer. 1995. Water Relations of Plants and Soils. Academic Press, New York.

Leuschner, C., K. Backes, D. Hertel, F. Schipka, U. Schmitt, O. Terborg, and M. Runge. 2001. Drought responses at leaf, stem and fine root levels of competitive Fagus sylvatica L. and Quercus petraea (Matt.) Liebl. Trees in dry and wet years. Forest Ecology and Management 149:33-46.

Levitt, D.G., J.R. Simpson and J.L. Tipton. 1995. Water use of two landscape tree species in Tucson, Arizona. Journal of the American Society of Horticultural Science 120:409-416.

Li, C. 2000. Population differences in water-use efficiency of Eucalyptus microtheca seedlings under different watering regimes. Physiologia Plant 108:134-139.

Liogier, H.A. 1990. Plantas Medicinales de Puerto Rico y. del Caribe. Iberoamericana de Ediciones, Inc., San Juan, PR 566p.

Makela, A., F. Berninger and P. Hari. 1996. Optimal control of gas exchange during drought. Theoretical analysis. Annals of Botany 77:461-467.

Menzel, C.M., A.G. Banks, and D.R. Simpson. 1986. Effect of aerial and soil environment on leaf water potential of lychee: Implications for irrigation scheduling and productivity. Acta Horticulturae 175:363-370.

Mielke, M.S., N.F. Barros, R.M. Penchel, C.A. Martinez, S. Fonseca and A.C. Almedia. 2000. Leaf gas exchange in a clonal eucalyptus plantation as related to soil moisture, leaf water potential and microclimate variables. Trees 14:263-270.

Morvant, J.K., J.M. Dole and J.C. Cole. 1998. Irrigation frequency and system affect poinsettia growth, water use and runoff. HortScience 32: 817-819.

Nardini, A, S. Salleo, M.A. Gullo, and F. Pitt, 2000. Different responses to drought and freeze stress of Quercus ilex L. growing along a latitudinal gradient. Plant Ecology, 148:139-147.

Ni, B.R. and S.G. Pallardy. 1991. Response of gas exchange to water stress in seedlings of woody angiosperms. Tree Physiology 8:1-9.

Nilsen, E.T. and D.M. Orcutt. 1996. The Physiology of Plant Under Stress. John Wiley and Sons, New York, USA.
Nobel, P.S. 1999. Physiochemical and Environmental Plant Physiology. $2^{\text {nd }}$ Ed. Academic Press, San Diego, CA, USA.

Parker, W.C. and S.G. Pallardy. 1988. Leaf and root osmotic adjustment in drought-stressed Quercus alba, Q. macrocarpa, and Q. stellata. Canadian Journal of Forestry Research 18:1-5.

Popp, M., U. Lüttge, W.J. Cram, M. Diaz, H. Griffiths, H.J.S. Lee, E. Medina, C. Schäfer, K.H. Stimmel and B. Thonke. 1989. Water relations and gas exchange of mangroves. New Physiologist 111: 293-307.

Ranney, T.G., N.L. Bassuk and T.H. Whitlow. 1991. Osmotic adjustment and solute constituents in leaves and roots of water-stressed cherry (Prunus) trees. Journal of the American Society of Horticultural Science 116:116-688.

Richter, H. 1997. Water relations of plants in the field: some comments on the measurement of selected parameters. Journal of Experimental Botany, 48: $1-7$.

Scholander, P.F., H.T. Hammer, E. Bradsteel and E.A. Henningsen. 1965. Sap pressure in vascular plants. Science, 148:339-346.

Shock, C., A. Akin, L.U. Unlenen, E. Feibert, K. Nelson, and A. Tschida. 2002. A comparison of soil water potential and soil water content sensors. In: Proceedings of the International Irrigation Show. Irrigation Association, Ontario, OR. 139-146.

Snedecor, G.W. and W.G. Cochran. 1980. Statistical Methods, $18^{\text {th }}$ ed. The Iowa State College Press. Ames, Iowa, USA.

Stevens, W.D., C. Ulloa, A. Pool, and O.H. Montiel. 2001. Flora de Nicaragua. Monographs of Systematic Botany Vol. 85, No. 1. Missouri Botanical Garden Press. 1-943.

Taiz, L. and E. Zeiger. 2002. Stress Physiology. In: Plant Physiology, $3^{\text {rd }}$ ed. Sinauer Associates, Inc., publishers, Sunderland, Massachusetts, USA. 591620.

Tuomela, K. 1997. Physiological and Morphological Responses of Eucalyptus microtheca Provenances to Water Availability in Tropical Drylands. University of Helsinki Tropic Forest Report. 1360.

Tyree, M.T., A. Nardini and S. Salleo. 2001. Hydraulic architecture of whole plants and single leaves. In: M. Labrecque (Ed) L'arbre 2000 The Tree. p 215221. Isabelle Quentin Publisher, Montreal. 
Vogt, U.K. and R. Lösch. 1999. Stem water potential and leaf conductance: a comparison of Sorbus aucuparia and Sambucus nigra. Physics and Chemistry of the Earth 24:121-123.
Wang, Z., B. Huang and Q. Xu. 2003. Effect of abscissic acid on drought response of Kentucky bluegrass. Journal of the American Society of Horticultural Science 128:36-41.

Received: August 2004

Accepted: November 2006 